\title{
The Impact of Urbanization on Food (in)Security in Amhara Regional State Metropolitan cities: Monitoring Income Generating Capacity Limitation as a Mediating variable
}

\author{
Besfat Engdaw ${ }^{1}$ and Melaku Kebede ${ }^{2}$ \\ ${ }^{1}$ Department of Governance and Development Studies, School of Law, Bahir Dar \\ University, Bahir Dar, Amhara ,Ethiopia, \\ ${ }^{2}$ Department of Governance and Development Studies, School of Law, Bahir Dar \\ University, Bahir Dar, Amhara, Ethiopia,
}

\begin{abstract}
As urbanization has occurred without the attendant growth and development spillovers in underdeveloped nations including Ethiopia, the phenomenon brought undesirable social and economic consequences. This paper investigates the influences of urbanization on food insecurity in Amhara metropolitan cities controlling incomegenerating capacity limitation as a mediating variable. A total of 622 households were selected from three metropolitan cities; 248 households from Gondar, 148 households from Dessie, and 226 households from Bahir Dar. The return rate of the questionnaires was $80.39 \%$. An analytical model is developed to provide insights into such effects. Structural Equation Modeling was used to run a mediation analysis through decomposing the direct and indirect effects of one variable on the other. Regression analyses were also carried out to measure the direction and magnitude of the effect of the independent variable on the dependent. Results provide evidence that urbanization has a significant impact on food insecurity. The study also depicts the mediating role of income generating capacity limitations in the relationship between urbanization and food insecurity. Accordingly, the indirect effect of urbanization on food insecurity (0.313), is greater than the direct effect (0.021). Therefore, the study concludes as income generating capacity limitation mediates the relationship between the two variables.

Henceforth, the study recommends policymakers to manage urbanization by dealing with rural-urban migration, unplanned outward expansion, and the natural growth in the urban as well as rural areas
\end{abstract}

which is not consistent with the urban economic growth.

Keywords; urban, urbanization, food security, income-generating capacity.

\section{Introduction}

Urbanization can be conceptualized as a process by which the large numbers of people become permanently concentrated in relatively small areas, forming cities.

There are three components of urban population growth: natural growth of urban population, ruralurban migration and the reclassification of areas previously defined as rural. The natural increase provides a base for urban population growth rates, and rural-urban migration and reclassification supplement this growth (Axel W. Drescher \& David L. Iaquinta, 2002).

People may move to the city because they are pushed by poverty from rural communities or they may be pulled by the attractions of city lives. The combination of these push and pull factors can also be one reason for moving into cities. In many parts of the developing world, rural population growth and the shortage of arable land are the major problems. Even though the land holding has been quite big in the rural area, it needs to be divided with several children and eventually; their children. These circumstances make migration the only opportunity to the farming people. Moreover, things are made worse by environmental deterioration (Gugler, 1997; Girardet, 1996).

For the first time in history, more than half of the world's population lived in urban areas in 2008 
(UN Population Fund, 2007). This urban population is projected to increase from 3.3 billion in 2008 to nearly 5 billion by 2030. At the beginning of the 20th century, the urban population was only 220 million, compared to the total global population of 1.65 billion. Regionally, the highest urbanization growth is taking place in Asia and Sub-Saharan Africa where the urban population is projected to be doubled from 2000 to 2030 .

Low and middle-income nations have more than three-quarters of the world's urban population (David Satterthwaite, Gordon McGranahan \& Cecilia Tacoli, 2010). Most of the nations with the fastest growing populations are now living in Africa, although this is a relatively recent phenomenon. But looking more properly at the urban population, in the period between1950-2000, in Africa the growth rate was the fastest in the world (4.4 percent a year) (Antonio Golini, 2001). The 2018 revision of world urbanization prospects by the United Nation Population Division shows that the average annual rate of change of the total population of Ethiopia is 2.43 for 2015-2020 whereas, the average annual rate of change of the percentage of urban population is 2.21 for the same period. From the data, it is clear that the majority of the increase in the total population is to take place in urban areas. According to official figures from the Ethiopian Central Statistics Agency, the urban population is projected to nearly triple from 15.2 million in 2012 to 42.3 million in 2037, growing at 3.8 percent a year (UN DESA, 2018).

A lot of studies have been carried out in the area of urbanization even though their findings left us unable to draw a clear picture of the phenomenon. Some earlier studies associate urbanization with economic development concluding the later causes the former. Others like Fay and Opal (2000) indicated that there is even "urbanization without growth" especially in sub-Saharan Africa. The traditional economic theory of urbanization which states, as the modern urban sector (i.e. manufacturing and service) expands, surplus labor from the "backward" rural economy (i.e. agriculture) is drawn to towns and cities attracted by higher wages (Lewis, 1954; Fei \& Ranis, 1964). On the other hand, the literature shows there has been urbanization in Africa in the late $20^{\text {th }}$ century despite economic stagnation. The history of preindustrial era shows factors such as limited food supply and high disease burdens in urban areas prevented urbanization and later on the alleviation of those problems through technological and institutional innovations in the eighteenth and nineteenth centuries brought back the urbanization process (Sean Fox, 2012). But since innovations have directly contributed both to mortality decline (hence, population growth) and economic development, it is possible to conclude that the economic development, which is the motive force behind urbanization, is spurious (Sean Fox, 2012). Whatever the cause, literature also indicates urbanization is a blessing. It is associated with a reduction in poverty "The urbanization process has played a quantitatively important positive role in overall poverty reduction by providing new opportunities to rural-out migrants" Ravallion M, Chen S, \& Sangraula P. (2007). Sustained economic growth is always accompanied by urbanization. This looks a little bit not the case for Africa. All these indicate the debate in the area. Hence, this paper is meant to contribute to the debate identifying the effect of urbanization on the society's welfare in the context of the Amhara region, Ethiopia.

\section{Review Literature 2.1 Urbanization}

Urbanization is defined in different ways by different scholars. Gordon McGranahan \& David Satterthwaite (2014), although proved that its widely used as more loosely and sloppily, defined urbanization as a massive rural-urban transition involving the shift in population from rural to urban locations, transforming rural landscape and livelihood. This actually implies that urbanization as a process of changes in demographic, economic and environmental conditions.

Urbanization is the process by which large numbers of people become permanently concentrated in relatively small areas, forming cities. Urbanization, on the other hand, defined as a relative growth in the country's urban population with faster economic, political and cultural development as compared with the rural area. It referred to an increase in humankind habitations as a result of increased per capita energy, resource consumption and extensive landscape modifications (Emma Pravitasari, 2015, as cited in McDonnell \& Pickett, 1990). Axel W. Drescher \& David L. Iaquinta (2002) also defined urbanization as the increase in the proportion of the population living in urban areas. In one or another way authors have tried to integrate urbanization with urban population growth, however, urbanization has economic, political and cultural dimensions.

Christopher Watson, (1993) also conceptualized urbanization in a physical and functional sense. In physical senses, urbanization is the use of land for the urban purpose. Basically, this definition of urbanization is simple and elementary that only considers the use of land for urban purposes. Besides, urbanization can be also conceptualized in a functional sense. This definition of urbanization focuses on people rather than land or physical 
structure. In a functional sense, urbanization encapsulates the social, economic and political activities of peoples to determine an area whether urban or not.

Among the dimensions to measure urbanization urban population growth is the basic one. Urban population growth has three important components; natural growth of urban population, rural-urban migration and reclassification of areas previously defined as rural (Stutz \& Souza, 1998). However, some authors, like Axel W. Drescher \& David L. Iaquinta (2002), have described in detail about ways how urbanization occurred. These are natural increase by urban dwellers, international migration, internal rural-urban migration, reclassification, and metropolitanization. First, natural growth is simply the excess of births over deaths in an area. Second, International migration is the movement of individuals crossing the national boundary. International migration could not be the primary causes of urban population growth in developing nations. It has a limited or insignificant impact on urban population growth. Third, internal ruralurban migration has always a significant contribution to urban population growth. Ruralurban migration has dual effects; on the one hand, it creates deruralization and on the other hand it significantly increases the population of urban areas (Axel W. Drescher \&David L. Iaquinta, 2002). Internal migration has happened as a result of two factors; pulling factors and pushing factors. Pulling factors are all sort of benefits that are existing in urban areas, e.g. education, health service, safe water services, huge commercial activities, easy transportation, advanced roads, efficient and effective services, improved lifestyles and etc. while the pushing factors are those which are forcing individuals, households, or families to leave their rural bases and relocated to the nearby cities or urban areas. These factors include limited agricultural land, natural disasters, social factors like conflict and decreasing agricultural land productivities etc. (Bahata B, 2010)

Fourth, reclassification or in-place of urbanization; it occurs when a certain location reaches the administratively defined threshold to be defined as urban. It depends on the demographic and administrative-political definitions.

Demographically, when the population of particular place increases and reaches the administratively defined threshold, the residents of rural could be reclassified to an urban one. Administratively, reclassification occurs with the perceived economic advantages and the capacity to absorb nonagricultural labor. And in some cases, reclassification could occur as a direct result of the annexation of areas of suburbs or non-urban. Thus, it happens by administratively integrating resident who had a non-urban lifestyle into urban residents (Axel W. Drescher \&David L. Iaquinta, 2002)

An urban area is a spatial concentration of people who are working in non-agricultural activities. The essential characteristic here is that urban means non-agricultural. Urban can also be defined as a fairly complex concept. Criteria used to define urban can include population size, space, density, and economic organization. Usually, however, urban is simply defined by some baseline size, like 20,000 people. Anyway, this definition varies between regions and cities (Long, 1998). The Ethiopian Central Statistical Agency's definition of urban is localities of 2000 or more inhabitants.

People may move to the city because they are pushed by poverty from rural communities or they may be pulled by the attractions of city lives. Combination of these push and pull factors can also be one reason for moving into cities. In many parts of the world, rural population growth and the shortage of arable land are the major problems. Even though the land holdings have been quite big they are to be divided with several children and eventually, their children. These circumstances make migration the only opportunity to the farming people. Things are made worse by environmental deterioration (Gugler, 1997; Girardet, 1996).

The normal push factors to rural people are the circumstances that make their earning of living impossible, land deterioration, lack of adequate land, unequal land distribution, droughts, storms, floods, and clean water shortages. These serious disadvantages make farming, the livelihood of rural people, hard and sometimes hopeless. Lack of modern resources, firewood shortages, religious conflicts, local economic declines, are also major reasons for moving to urban areas (Gugler, 1997; Girardet, 1996).

For the first time in history, more than half of the world's population lived in urban areas in 2008 (UN Population Fund, 2007). This urban population is projected to increase from 3.3 billion in 2008 to nearly 5 billion by 2030. At the beginning of the 20th century, the urban population was only 220 million, compared to the total global population of 1.65 billion. Regionally, the highest urban growth is taking place in Asia and SubSaharan Africa where the urban population is projected to double from 2000 to 2030 .

\subsection{Causes of urbanization}

Studying the causes of urbanization is one of the major scholarly interest. As urbanization becomes an evident and ever-growing phenomenon in the world, scholars devoted to depicting what possibly causes it. It could be gaffed if one considered the common causes of urbanization in the world. Taking the historical importance and development 
patterns of nations, there could be different causes to urbanization. For example, in Europe industrialization contributed a lot to rapid urbanization. Industrialization, mechanization agriculture and commercialization have attracted a large number of labors from the countryside to the cities, which it, in turn, speeds up the process of urbanization. However, in developing nations like Africa industrialization didn't play roles in the process of urbanization. In Africa, urbanization has been induced with rural-urban migration without having labor-intensive industries in the cities and natural increase of population in urban areas (Emma Pravitasari A., 2015).

Until recently the scholarly analysis attributed immigration as a primary cause of urbanization. It is also the main causes of population growth in urban areas, particularly in third world country. However, after 1950 rapid urban population growth scholars proved that migration is not the only causes of urban population growth. Since then natural population growth (reproduction) and physical expansion of cities to rural area contributed to increasing urban population growth. (Emma Pravitasari A., 2015)

Apart from the above three primary factors, there are also several causes of urbanization such as a) industrial revolution b) industrialization following the industrial revolution c) emergence of large manufacturing centers; d) job opportunities; e) availability of easy transportation. These factors coupled with other benefits of urbanization, i.e. economic improvement, huge commercial activities, socio-cultural integration, and efficient and effective service, have been attracting a number of migrants into cities, which in turn increases the processes of urbanization. (ibid, 2015).

Although it is implicitly similar with Axel W. Drescher \&David L. Iaquinta \& Emma Pravitasari, Pawan (2016) has also identified industrialization, social factors, modernization, commercialization, economic and job opportunities as the causes of urbanization. Industrial growth or industrialization created expanded economic and job opportunities that in turn facilitates rural-urban migration. Whereas, commercialization and trade accord cities and urban area better commercial opportunities and return, which it increases the rate of urbanization. Social factors are other reasons for the rapid urbanization process. This means the abundance of social services like education, health services, better living standards, and effective and efficient service have long been contributed for the dislocation of individuals, households, and families from the rural side into urban settings. The last but not the least causes of urbanization according to Pawan is modernization. Urban areas have at least relative advantage to technological advancement. Hence, they are equipped with sophisticated technologies, better infrastructural development, and communication that attracted many peoples to come from the rural areas.

Although scholars have prescribed different causes to urbanization; natural growth, migration, and reclassification are notably the common causes of urbanization shared by almost all scholars.

Urbanization could pass certain stages of development. Hence, it is difficult to lump up the level of urbanization in the world in the same pot. Hence, it should be fair to judge nations or countries with certain standards about their level of urbanization. Changchun Feng et al (2016) as cited in Northam (1979) has identified three stages in discussing the levels of urbanization. A country would be in the first stages of urbanization when urban population covers $10 \%$ of the total population. A country would be in the second stages of urbanization when its urban population covers $30 \%$ of the total population. And finally, a country would be in the third stages of urbanization when its urban population covers $70 \%$ above of the total population

\subsection{Theories of Urbanization}

The early or classical theory of urbanization was developed by Lewis. Homayoun Pasha Safavi (2012) as cited in Ma (2011) claimed that Lewis model concentrating on dual economy takes ruralurban migration as the equilibrium mechanisms of surplus labor, which it withdraws from the rural sector with almost zero marginal productivities to modern urban sector. With the same analogy, Harris Todaro has developed a model with the intent to explain rural-urban migration dynamics. The driving force behind rural-urban migration is access to wage employment. The surplus labor deployed in agricultural production which is abundant in the rural area could be shifted to urban area whereby they engaged in manufacturing productions. Harris Todaro has also argued that rural-urban migration continues as long as urban minimum wage exceeds agricultural production returns (Todaro \& Harris, 2009). Both Lewis and Harris Todaro affirmed rural-urban migration as the cause of urban population growth and urbanization.

Homayoun Pasha Safavi (2012) as cited in Kasarda and Crenshaw (1991) has affirmed that there are three main theories of urbanization. These are modernization theory, dependency theory, and urban bias theory. 


\subsubsection{Modernization theory}

This theory was actually developed in the aftermath of the Second World War. The theory basically has something to do with the process of development, but the way it conceptualized development has intrinsically intertwined with urbanization. For modernization theory, development means the transformation of traditional society who are entirely depending on agriculture into modern societies who entirely depend on the industry. Modernization theory introduced an idea that by introducing modern methods of production like the use of advanced technology to the industries of underdeveloped countries, it's possible to get strong the economies and brings about development. According to modernization theory, there will not be urbanization without industrialization. This means more industrialized countries are more likely urbanized. (Christian Tettey, 2005).

Kasarda \& Crenshaw (1991), indicated that modernization theory has three main concepts. Accordingly, the process of urbanization and development are interrelated and connected to the process of modernization. The second concept is that technology is a significant and important factor in the process of urbanization and modernism. The last concept has actually something to do with cultural diffusion which eventually imposes the convergence of first and third world countries development pattern.

Modernization theory explains the process of urbanization in third world countries. The theory describes it with references to the dichotomized economy (traditional/modern) and demographic transition theories. City building in the third world countries is attributable to cultural lag particularly in equilibrating fertility and mortality and ruralurban migration induced by push and pull factors.

\subsubsection{Dependency Theory}

Dependency theory has emerged in the 1960s within the third world nations by third world scholars. It was initially instituted as a counter reaction for modernization theory premises (Alex Hadenuis, 1992). Dependency theory holds that development in the developing nation is the reflection of the growth and expansion of development in the western world. As cities in the metropolis expand and their economies outgrow, reflecting it, cities in developing nations could grow and expand. This entails the dependent relationship between center and periphery. Which actually constitutes the primary causes of underdevelopment of underdeveloped nations.

Christian Tettey, (2005) has tried to clearly depict urban development with respect to dependency theory. It argued that change that would have occurred in the structure of the cities is a result of the paradigm shift from pre-capitalist to the capitalist mode of production. Dependency theory has also focused on the dependent nature of capitalists on the resources of third world countries. As a result of this third world countries have attracted large foreign investment in agricultural sectors which displaces a number of farmers from their rural base and forced them to migrate to the urban area in search of jobs. On the other hand, the large-scale foreign investment in capital incentive manufacturing sectors increased output and speeded up industrialization in the urban area. This has created a pseudo impression of better jobs and employment opportunities in urban areas than rural areas. Consequently, the large number of people are adored to migrate to urban areas. That in turn speed up the process of urbanization.

\subsubsection{Urban Bias theory}

The above two theories addressed urban development from economic perspectives. However, this theory has actually looked at urban development from policy-making perspectives. Urban bias theory was postulated by Michael Lipton in 1977. Lipton argued that policies in developing nations are favoring the urban center as infrastructures, development activities, and facilities like health, education, water, and sanitation, are expanding swiftly in the urban area. However, rural areas have been suffering from policy negligence and deterrence. (Ashutosh, 1993 \& Christian Tettey, 2005). Rural areas where the bases of agricultural production were suffered from state policy deterrence like over taxation, agricultural price distortion, systematic reshuffling agricultural production to urban centers. The systematic detriment of state policy against rural area is also revealed in states policy negligence as it ill-expands infrastructures, health, education, road, water electricity in the rural area while most of the national gross domestic product comes thereof (Ashutosh, 1993 \& Christian Tettey, 2005). This has been contributing a lot for people to migrate from rural to the urban area in seeking better living conditions.

\subsection{The process and trends of Urbanization in Ethiopia}

The present processes of urbanization in Ethiopia can't be seen in alienated with its antiquated background. Hence, urbanization in Ethiopia dated back to the $4^{\text {th }}$ century with the genesis of Aksumite civilization. In ancient Aksumite, there were important towns serving as centers of commerce, administration, and culture. In the mid- $11^{\text {th }}$ century 
the Zagwe Dynasty shifted the town from Aksum to Lalibela. Again six centuries later another urban civilization was flourished at Gondar (UN Habitat, 1996).

Many reasons were accounted for the growth of towns and the expansion of urbanization in northern Ethiopia. Among these, the expansion of trade and center of political administrations are the notable ones. However, there had been exceptional historic towns that had astonishing urban growth in the south and Easter part of the country such as Jimma and Harar (UN Habitat, 1996).

No one can assure that the process of urbanization in Ethiopia before $19^{\text {th }}$ century was rapid rather it was very limited because of different reasons. The first import reason was frequent mobility of government center. The second reason was a low level of trade as a result of lack of peace and security. However, toward the turn of the last quarter of $19^{\text {th }}$ century, during the reign of Emperor Menelik II, there was an established permanent political center which is situated at Addis Abeba. Consequently, a number of new settlements were flourished along with roads and communication lines connecting to the central city. Apart from this, there had been large-scale urbanization in Ethiopia during the Italian occupation.

Although urbanization started to grow and new urban centers were flourished, it can be clearly concluded that there was an interregional disparity in the level of urbanization in Ethiopia. The level of urbanization in Ethiopia is known as one of the least in Africa (UN Habitat, 1996).

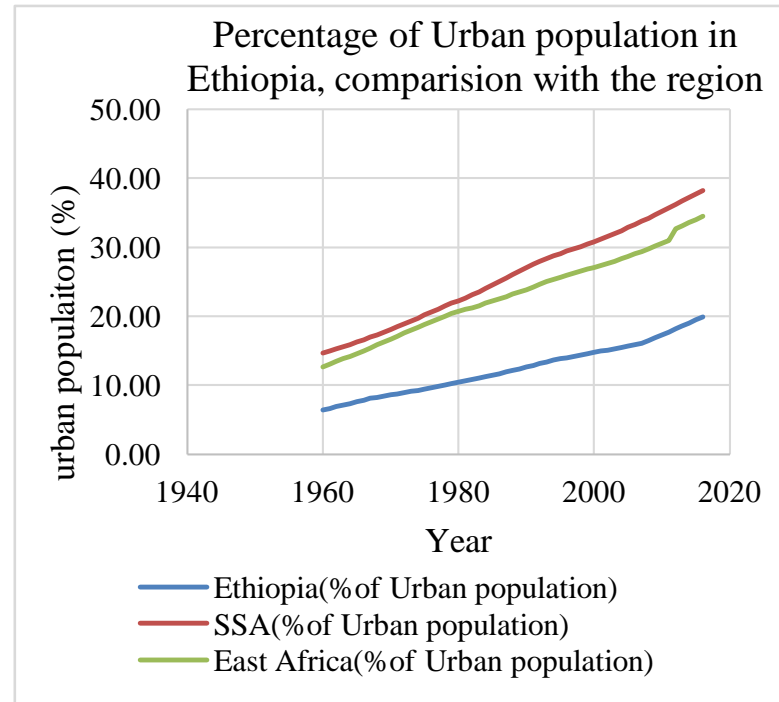

Figure 1 Trends of urban population in Ethiopia, computed Based on the United Nations Population Divisions World Urbanization Prospects.

Looking at the above figure whereby the trends of urban population growth of Ethiopia is fully pictured, it is surely possible to hold that Ethiopia is still least urbanized compared to the average East and Sub Saharan African levels of urbanization. The figure clearly shows that there is an enormous gap between Ethiopia and East and Sub Saharan African. Ethiopia had only $6.43 \%$ of urban population in 1960 and a decade later very slight increases were registered as only $8.59 \%$ of its population were urban. From the year 1960-2000, the urban population of Ethiopia increased with around $2 \%$ of differences in every decade. However, from the year 2000-2016 the proportion of people who have lived in the urban area increased with around $2.6 \%$ differences. Nowadays, around $20 \%$ of the people are meant to be living in urban areas. This is very low as compared with the East African (34.5\%) and Sub Saharan level of urbanization (37.75\%). Nevertheless, Ethiopia has a fast growth rate of the urban population compared to its historical background. Ethiopia had 15.2 million urban population in 2012 which it was projected to be tripled by the year 2037 having 42.3 million urban populations with $3.8 \%$ of growth rate (World Bank, 2015). Besides, the urban annual growth rate had shown a steady upswing in Africa. In supporting this, a statistical data from Population Division of the Department of Economic and Social Affairs of the United Nation (2010) confirmed that Ethiopia had $5.87 \%$ annual urban growth rate from 196065. From 1965-70 it had 5.16\% of urban annual population growth rate. The annual urban growth rate in Ethiopia was around $3.57 \%$ from the year 1975-80. However, from 1985-90, the annual urban growth had shown dramatic upsurges as it was $5.04 \%$. From 2005-2010 the annual urban growth rate was around $4.29 \%$. Despite Ethiopia is still one of the least urbanized countries in Africa, its rate of urbanization has shown an enormous increment. Moreover, Tesegaye Tegenu(2010), holds that the number of towns and cities in 1960 were 384 . The number of cities and towns had increased to 549 which is nearly doubling the number of towns and cities in the 1960s. In the year 1984, this number had actually turned over 710 that showed $29.3 \%$ of variations as compared with 1970 . In addition, by the year 1994 and 2008, the number of cities and town was 925 and 927 respectively.

Although UNECA (2017) leveled Ethiopia as one of the countries that have been rigorously investing in infrastructural development, rapid urbanization has posed several serious challenges as other African countries do. Among these challenges expanded slums and sprawl, housing problems, unemployment, inadequate social development, urban poverty and transportation problem etc (Haregewoin Bekele, 2005; Tesegaye Tegenu, 2010). 


\subsection{The process and trends of Urbanization in Amhara}

Amhara region is one of the regions that shows rapid urbanization process in Ethiopia. The region has an urban population growth rate of $4.9 \%$ from 1995-2000 which is above the rate of urban population growth at national level. The region had an urban population growth rate which is ranked second next to Oromia region. From 2001-2005 the region has $4.4 \%$ of urban population growth rate. In 2007 the region had a total of 208 cities and towns, which contributes to $11.7 \%$ of urban population in the same year. This is higher than the 1994 urban population percentage, which was around $8.5 \%$. In 1994 census result, In the region, Semen Gondar zone has the highest urban population proportion $(18.7 \%)$ followed by South Wollo (16.7\%), North Shoa(11.6\%) and East Gojjam (11.5\%). South Gonder and West Gojjam have also $9.2 \%$ and $8.5 \%$ of urban population followed by Bahir Dar special Zone, which has $7.6 \%$ of urban population proportion (Antonio Golini, 2001; BoFED, 2014).

The population of Bahir Dar has increased from 54,800 in 1984 to 96,140 in 1994 with an average growth rate of $5.6 \%$ and in 2007 the population increased to 155,428 with 3.7 average growth rate. In 2014, it reached 226,713. On the other hand, Gondar city had 80,886 populations. From the year 1984-1994 the population raised to 112,249 with an average growth rate of 3.3. The population growth has shown tremendous upsurge to 207,044 in 2007 with an average growth rate of 4.7. The other major cities found in Amhara region is Dessie. Alike Gondar and Bahir Dar city administration, Dessie has also experienced fast growing urban population. In the year 1984 the population was 68,848 and in 1994 it turns to 97,314 with an average growth rate of 3.5 and in 2007 it reached 120,095 with an average growth rate of 1.6. Therefore, there have been fast growing urbanization processes in the region comparatively (MUDHCo \& ECSU, 2015). However, the fast growing urbanization has created serious challenges in food security and limited income generating capacity.

\subsection{Urbanization and food security}

Nearly 240 million people in sub-Saharan Africa, or one person in every four, lack adequate food for a healthy and active life, and record food prices and drought are pushing more people into poverty and hunger. At the same time, the world's population has now surpassed 7 billion, and news headlines that in the past have asked "Can we feed the world?" are beginning to ask the equally important question, "How many will there be to feed?" (Jason Bremner, 2012).
How much additional food is needed to feed the world in 2050 depends on future fertility. Population growth will greatly increase the amount of food needed to adequately feed sub-Saharan Africa's people. Ira Matuschke (2009), if unabsorbed, urbanization may lead to the development of slums and pose a considerable threat to all dimensions of food insecurity, because the majority of urban dwellers are net food buyers and spend a large part of their disposable income on food. In particular, the 2007/2008 food crisis demonstrated the vulnerability of the urban poor and the strong link between food and national security. When prices for staple food crops - like wheat, maize, and rice- started to rise at the end of 2007 and reached decade highs in early 2008, the urban poor were hit the hardest. This led to food related riots and conflicts.

If cities do not adapt to their new realities, the expected boost in urbanization and population growth could further increase the vulnerability of urban dwellers to sudden shocks in agricultural markets. To avoid such kind of scenario, policymakers should have to react these risks by developing strategies that address urban food security.

Small to medium-sized cities, particularly in developing countries, often lack infrastructure and basic services- like water, sanitation, electricity, health care, and waste disposal- to absorb an ever increasing number of people (Cohen, 2006; Montgomery, 2008). This frequently leads to the development of city slums, which are defined as low-income, overcrowded settlements with poor human living conditions (UN-HABITAT, 2003).

Uncontrolled urbanization and low absorption capacities by cities have a strong effect on poverty rates. A recent study by Chen \& Ravallion (2007) found that poverty rates are becoming more and more urbanized. The authors established that, despite the fact that the majority of the poor continues to reside in rural areas, the incidence of urban poverty in comparison to total poverty incidence increased with urbanization. This essentially signifies that the poor urbanized faster and/or that urban poverty decreases slower in comparison to rural areas (Chen \& Ravallion 2007).

\subsection{Urbanization, Income generating capacity, and Food security}

Food insecurity is an emerging urban problem that requires a lot of attention by policy makers. To alleviate the problem focusing on increasing agricultural food production is not the main solution to the urban poor. The low and irregular income is the root cause to food insecurity of urban residents as it has effect on access and affordability 
to them. More than half the world's population lives in urban centers, and urban food insecurity is an emerging challenge that is exacerbated by the climate change. Addressing urban food security requires attention to incomes, living conditions, access to formal and informal markets and the interconnections between rural and urban food security (Tacoli C., 2013).

Urbanization largely affects the income generating capacity of urban dwellers as the available job opportunities are not commensurate with the ever increasing urban population and as a result of other socio-economic problems such as lack of affordable houses in urban areas. This in turn has a profound effect on food security and poverty of urban dwellers. That is to say insufficient income is the major cause of urban food insecurity. "In many low and middle-income countries, the unwelcome corollary of rapid urbanization is rising numbers of people with low and unstable incomes who live in settlements with inadequate infrastructure and limited if not non-existing basic services. Poverty and food insecurity are deeply interconnected. With the majority of the world's population living in urban centers, poverty increasingly becomes an urban issue and so does food security (Tacoli C., 2013)".

The proportion of food consumption expenditure by the urban poor accounts about more than 50 percent of their total earnings and any decline in their incomes that are already low has a large negative impact on their livelihood. It is also indicated that in eleven Southern African cities four out of five urban households are food insecure. A common coping response is reducing the quality and quantity of food and skipping meals, while at the same time working longer hours (Tacoli C., 2013).

Improving access to affordable food by the urban poor will require boosting their capacity to adapt to climate change impacts, and their access to secure incomes and to both formal and informal food markets. (Tacoli C., 2013)

\section{Materials and Methods}

A household survey was conducted in three metropolitan cities of Amhara region: Bahir Dar, Gondar, and Dessie. From the total population of 170456, a sample of 622 households (248 households from Gondar, 148 households from Dessie, and 226 households from Bahir Dar) were selected using a proportionate stratified sampling method. From the 622 questionnaires distributed to the households 500 were returned to the researchers. The return rate of the questionnaire was 80.39 percent.

\subsection{Specification of the Model}

A binary logistic regression model has been used to elicit the effect of urbanization on food insecurity. The model uses food insecurity among households as the dichotomous dependent variable. The model is given by;

$$
\begin{aligned}
& \ln \left[\frac{\mathrm{p}}{1-\mathrm{p}}\right]=\mathrm{b}_{0}+\mathrm{b}_{1}(\mathrm{x}) \\
& \text { Where: }
\end{aligned}
$$

$\mathrm{Ln}=$ the natural logarithm

$\mathrm{P}=$ the short form of $\mathrm{p}(\mathrm{y}=1)$ - the probability that the dependent variable exists

$\frac{\mathrm{p}}{1-\mathrm{p}}=$ the odds for $\mathrm{p}(\mathrm{y}=1)$

$\ln \left[\frac{\mathrm{p}}{1-\mathrm{p}}\right]=$ natural $\log$ arithm of the odds for $\mathrm{p}(\mathrm{y}=1)$

The model is based on the following hypotheses:

a) Urbanization affects income generating capacity of citizens negatively.

b) Urbanization affects food security negatively

c) Income generating capacity affects food insecurity.

d) Income generating capacity mediates the relationship between urbanization and food security.

Concerning mediation analysis, the approach used by Baron \& Keny (1986) is followed. Four conditions must be fulfilled to evidence a mediating effect. First, the independent variable must significantly impact the dependent variable. Second, the independent variable must have impact on the mediator. Third, the mediator must impact the dependent variable. Finally, the effect of the independent variable on the dependent variable becomes less when the mediator is controlled, as shown by the change in regression coefficient. Full mediation exists when such an effect becomes nonsignificant.

\section{Reliability Test Results for Questionnaire}

Table 1 Reliability Test for Food Insecurity Questionnaire

\begin{tabular}{lllll}
\hline Item & $\begin{array}{l}\text { item-test } \\
\text { correlat } \\
\text { ion }\end{array}$ & $\begin{array}{l}\text { item- } \\
\text { rest } \\
\text { correlat }\end{array}$ & $\begin{array}{l}\text { Average } \\
\text { inter-item } \\
\text { Covarianc }\end{array}$ & Alpha \\
\hline FS1 & 0.5797 & 0.4982 & 0.18572 & 0.7534 \\
FS2 & 0.5538 & 0.466 & 0.186726 & 0.7553 \\
FS3 & 0.6202 & 0.5284 & 0.178491 & 0.7491 \\
FS4 & 0.5886 & 0.4945 & 0.181604 & 0.7521 \\
FS5 & 0.6399 & 0.5683 & 0.182410 & 0.749 \\
FS6 & 0.5243 & 0.4297 & 0.188043 & 0.7576 \\
FS7 & 0.5043 & 0.4178 & 0.191368 & 0.759 \\
FS8 & 0.5657 & 0.4913 & 0.188885 & 0.7551 \\
FS9 & 0.5115 & 0.4289 & 0.191571 & 0.7586 \\
FS10 & 0.1297 & 0.003 & 0.216186 & 0.7879 \\
FS11 & 0.1861 & 0.076 & 0.211496 & 0.7806
\end{tabular}




\begin{tabular}{l|llll} 
FS12 & 0.3657 & 0.2574 & 0.199267 & 0.7695 \\
FS13 & 0.3048 & 0.1932 & 0.203403 & 0.7737 \\
FS14 & 0.2295 & 0.1158 & 0.208764 & 0.7788 \\
FS15 & 0.147 & 0.0215 & 0.214856 & 0.7865 \\
FS16 & 0.6131 & 0.5383 & 0.184182 & 0.751 \\
FS17 & 0.5673 & 0.4914 & 0.188358 & 0.7548 \\
FS18 & 0.4956 & 0.4026 & 0.190888 & 0.7597 \\
FS19 & 0.3861 & 0.2629 & 0.196537 & 0.7702 \\
FS20 & 0.2563 & 0.1635 & 0.207364 & 0.774 \\
\hline Test & & & 0.194807 & $\mathbf{0 . 7 7 3 4}$ \\
scale & & & & \\
\hline fs-food security & & &
\end{tabular}

Table 2 Reliability Test for Urbanization Questionnaire

\begin{tabular}{lllll}
\hline \multicolumn{1}{c}{ Item } & $\begin{array}{l}\text { item- } \\
\text { test } \\
\text { correla } \\
\text { tion }\end{array}$ & $\begin{array}{l}\text { item- } \\
\text { rest } \\
\text { correlati } \\
\text { on }\end{array}$ & $\begin{array}{l}\text { average } \\
\text { inter-item } \\
\text { covarianc }\end{array}$ & alpha \\
& 0.772 & 0.7241 & 0.472295 & 0.7613 \\
\hline UR1 & 0.7376 & 0.6841 & 0.478424 & 0.7644 \\
UR2 & 0.7353 & 0.6801 & 0.476694 & 0.7639 \\
UR3 & 0.6903 & 0.6298 & 0.486852 & 0.7684 \\
UR4 & 0.7728 & 0.7241 & 0.470416 & 0.7607 \\
UR5 & 0.7493 & 0.6968 & 0.475159 & 0.763 \\
UR6 & 0.7513 & 0.6965 & 0.470686 & 0.7616 \\
UR7 & 0.5039 & 0.2304 & 0.48607 & 0.8449 \\
UR8 & 0.7295 & 0.6742 & 0.47908 & 0.7648 \\
UR9 & 0.4764 & 0.2006 & 0.498884 & 0.8482 \\
UR10 & 0.7448 & 0.6908 & 0.474533 & 0.763 \\
UR11 & & & & \\
\hline Test scale & & & 0.479008 & $\mathbf{0 . 7 9 3 8}$ \\
\hline \multicolumn{2}{c}{ ur-urbanization } & & &
\end{tabular}

Table 3 Reliability Test for Limited Income Generating Capacity Questionnaire

\begin{tabular}{lllll}
\hline Item & $\begin{array}{l}\text { item- } \\
\text { test } \\
\text { correlat } \\
\text { ion }\end{array}$ & $\begin{array}{l}\text { item- } \\
\text { rest } \\
\text { correla } \\
\text { tion }\end{array}$ & $\begin{array}{l}\text { Average } \\
\text { Inter-item } \\
\text { covariance }\end{array}$ & alpha \\
\hline IGC1 & 0.6237 & 0.5661 & 0.393063 & 0.8837 \\
IGC2 & 0.6011 & 0.5397 & 0.394283 & 0.8846 \\
IGC3 & 0.6225 & 0.5631 & 0.391903 & 0.8837 \\
IGC4 & 0.6558 & 0.5981 & 0.387268 & 0.8823 \\
IGC5 & 0.5766 & 0.5073 & 0.393432 & 0.8856 \\
IGC6 & 0.5871 & 0.4942 & 0.38048 & 0.8868 \\
IGC7 & 0.7319 & 0.6636 & 0.359864 & 0.8777 \\
IGC8 & 0.7413 & 0.6699 & 0.354808 & 0.8774 \\
IGC9 & 0.699 & 0.6269 & 0.366511 & 0.8798 \\
IGC10 & 0.6965 & 0.624 & 0.366827 & 0.8799 \\
IGC11 & 0.7011 & 0.6217 & 0.360997 & 0.8802 \\
IGC12 & 0.7119 & 0.6313 & 0.356693 & 0.8798 \\
IGC13 & 0.6391 & 0.5454 & 0.368547 & 0.8848 \\
\hline Test scale & & & 0.374974 & $\mathbf{0 . 8 9 0 2}$ \\
\hline IGC-income generating capacity & &
\end{tabular}

As indicated in table 1, 2, and 3, before the questionnaire, get distributed the researchers computed the reliability of the questionnaire for each variables. In doing so Cronbach's alpha is computed. Looking at the above tables the Cronbach's alphas for Urbanization, food insecurity, and Limited income generation capacity are $0.794,0.773$, and 0.8902 respectively. Therefore, the results indicated in the above tables confirmed that there is high inter item consistency among questions as the results are higher than 0.70 .

\section{Results and Discussion}

Based on the data obtained from 500 households, we have run the binary logistic regression. And the results are presented as follows.

\subsection{Regression Analysis \\ 4.2 \\ 4.2.1 Urbanization and Limited Income generating capacity}

Table 4 Logistic regression coefficient result of urbanization and income generating capacity

Income generating Coef. St.Err t-valu p- Sig. capacity_cat value

\begin{tabular}{lccll}
\hline Urbanization_cat & 5.369 & 0.792 & 6.78 & 0.000 \\
_cons & 0.981 & 0.677 & -1.45 & 0.147 \\
\hline $\begin{array}{l}\text { Mean dependent } \\
\text { var }\end{array}$ & 0.972 & SD dependent & 0.165 \\
Pseudo r-squared & 0.392 & Number of obs & 500.00 \\
Chi-square & 50.095 & Prob > chi2 & 0.000 \\
Akaike & crit. & 81.624 & Bayesian crit. & 90.053 \\
(AIC) & & (BIC) & \\
\hline
\end{tabular}

$* * * \mathrm{p}<0.01, * * \mathrm{p}<0.05, * \mathrm{p}<0.1$

Table 5 the odds ratio of urbanization and income generating capacity

\begin{tabular}{|c|c|c|c|c|c|}
\hline $\begin{array}{l}\text { Income } \\
\text { generating } \\
\text { capacity_cat }\end{array}$ & \multicolumn{2}{|c|}{ Coef. } & St.Err & $\begin{array}{ll}\text { t-value } & \mathrm{p}- \\
& \text { value }\end{array}$ & Sig. \\
\hline $\begin{array}{l}\text { Urbanization_ } \\
\text { cat }\end{array}$ & \multicolumn{2}{|c|}{214.667} & 169.99 & 0.000 & $* * *$ \\
\hline _cons & \multicolumn{2}{|c|}{0.375} & 0.254 & -1.45 & \\
\hline \multicolumn{2}{|c|}{$\begin{array}{l}\text { Mean dependent } \\
\text { var }\end{array}$} & \multicolumn{2}{|c|}{0.972} & $\begin{array}{l}\text { D dependent } \\
\text { var }\end{array}$ & 0.165 \\
\hline \multicolumn{2}{|c|}{ Pseudo r-squared } & \multicolumn{2}{|c|}{0.392} & Number of obs & 500.00 \\
\hline Chi-square & & & 095 & \multirow{2}{*}{$\begin{array}{l}\text { Prob > chi2 } \\
\text { Bayesian.crit. } \\
\text { (BIC) }\end{array}$} & 0.000 \\
\hline \multicolumn{2}{|c|}{ Akaike.crit. (AIC) } & \multicolumn{2}{|c|}{81.624} & & 90.053 \\
\hline
\end{tabular}


From table 4 and 5, we observed that when there is urbanization $(X=1)$ the odds of limitations in income generating capacity $(Y=1)$ is 214.6 times greater than the odds of limitations in income generating capacity in the absence of urbanization $(X=0)$. This indicates that if there is urbanization the likely hood that citizens will have a limited income-generating capacity is higher than the case that $x=0$. Hence, we conclude that urbanization brings limitations in incomegenerating capacity. Consequently, hypothesis (a) is ascertained.

To put it the other way, the probability that urbanization causes income generating capacity limitations is $\mathrm{P}=\frac{\mathrm{e}^{\mathrm{bo}+\mathrm{bl}(\mathrm{x})}}{1+e^{\mathrm{bo}+\mathrm{b} 1(\mathrm{x})}}$. From the table, we see that the values of $b 0=-0.98 b 1=5.37$.

Therefore, $\mathrm{p}=\left(\frac{\mathrm{e}^{-0.98+5.37(\mathrm{x})}}{1+e^{-0.98+5.37(\mathrm{x})}}\right)$ then for $\mathrm{x}=1 \mathrm{p}=$ $2.7182^{-0.98+5.37(1)}$

$\overline{1+\left(2.7182^{-0.98+5.37(1)}\right)}$

$=\frac{80.63}{81.63}=0.987$, this shows when there is urbanization the probability that there will be a limitation in income generating capacity is 0.987 or $98 \%$ of the times. Whenever there is urbanization there is limitation in income generating capacity of citizens.

Moreover, descriptive statistics have been solicited to depict out the limitations of the income generating capacity of urban residents. The disposable income, and total expenditure of the citizens have important information to convey about the income generating capacity of citizens. Table 6,7,8,9, clearly show the income, expenditure, and, employment gap and length of time a citizen stayed unemployed.

Table 6 Monthly Disposable Income of the Respondents

\begin{tabular}{llll}
$\begin{array}{l}\text { Disposable } \\
\text { Income }\end{array}$ & Freq. & Percent & Cum. \\
\hline $0-999$ & 72 & 14.40 & 14.40 \\
$1000-1999$ & 211 & 42.20 & 56.60 \\
$2000-2999$ & 105 & 21.00 & 77.60 \\
$3000-3999$ & 53 & 10.60 & 88.20 \\
$4000-4999$ & 26 & 5.20 & 93.40 \\
$5000-5999$ & 12 & 2.40 & 95.80 \\
$6000-6999$ & 6 & 1.20 & 97.00 \\
$7000-7999$ & 1 & 0.20 & 97.20 \\
$8000-8999$ & 2 & 0.40 & 97.60 \\
Missed outliers & 12 & 2.40 & 100.00 \\
\cline { 1 - 2 } Total & 500 & 100.00 &
\end{tabular}

Table 7 : Monthly Expenditure of Respondents

\begin{tabular}{llll}
\hline $\begin{array}{l}\text { Total } \\
\text { expenditure }\end{array}$ & Freq. & Percent & Cum. \\
\hline $0-599$ & 29 & 5.80 & 5.80 \\
$600-1199$ & 137 & 27.40 & 33.20 \\
$1200-1799$ & 146 & 29.20 & 62.40 \\
$1800-2399$ & 90 & 18.00 & 80.40 \\
$2400-2999$ & 38 & 7.60 & 88.00 \\
$3000-3499$ & 21 & 4.20 & 92.20 \\
$3500-4099$ & 8 & 1.60 & 93.80 \\
$4100-4699$ & 5 & 1.00 & 94.80 \\
$4700-5299$ & 3 & 0.60 & 95.40 \\
$5300-5899$ & 8 & 1.60 & 97.00 \\
$5900-6499$ & 1 & 0.20 & 97.20 \\
Missed outliers & 14 & 2.80 & 100.00 \\
\cline { 1 - 2 } Total & 500 & 100.00 & \\
\hline
\end{tabular}

From table 6 and 7 we see that $97 \%$ of the respondents' monthly income ranges from $0-7000$ birr and their monthly expenditure ranges from $0-$ 6000 birr which indicates they almost spend what they have earned. In table 6 majority of the respondents which constitute $56 \%$ have monthly disposable income less than 2000 birr or $70 \$$. This means that $56 \%$ of the respondents are earning less than $2.3 \$$ per day. On the other hand, as clearly shown in table $7,80.4 \%$ of the respondents have expenditures reaching up to 2300 birr or $84 \$$. From this, we can easily understand how much their saving and further income-generating capacity is very weak.

Table 8 Employment Status of respondent

Employment Status Freq. Perce Cum.

\begin{tabular}{llll} 
& & nt & \\
\cline { 1 - 2 } Unemployed & 139 & 27.80 & 27.80 \\
Employed & 154 & 30.80 & 58.60 \\
Doesn't concern me & 193 & 38.60 & 97.20 \\
Missed & 14 & 2.80 & 100.00 \\
\cline { 1 - 2 } Total & 500 & 100 &
\end{tabular}

Table 9 Length of year of Employment Gap

\begin{tabular}{llll}
$\begin{array}{l}\text { Employment } \\
\text { Gap (yearly) }\end{array}$ & Freq. & Percent & Cum. \\
\hline $0-0.249$ & 2 & 0.40 & 0.40 \\
$.25-0.49$ & 8 & 1.60 & 2.00 \\
$.5-0.99$ & 10 & 2.00 & 4.00 \\
$1-1.99$ & 59 & 11.80 & 15.80 \\
$2-2.99$ & 26 & 5.20 & 21.00 \\
$3-3.99$ & 25 & 5.00 & 26.00 \\
$4-4.99$ & 3 & 0.60 & 26.60 \\
$5>=$ & 1 & 0.20 & 26.80 \\
Missed & 366 & 73.20 & 100.00 \\
\cline { 1 - 2 } Total & 500 & 100.00 & \\
\cline { 1 - 1 } & \multicolumn{3}{l}{}
\end{tabular}

From table 8 and 9 we observe that on average an individual remains unemployed for 2 years which 
is an addition to the problem of income generating capacity limitations of citizens in rapidly urbanizing underdeveloped areas like Amhara region metropolitan cities.

\subsubsection{Income generating capacity limitations and Food insecurity}

Table 10 Logistic regression coefficient result of income generating capacity limitations and food insecurity

\begin{tabular}{|c|c|c|c|c|c|}
\hline $\begin{array}{l}\text { Food } \\
\text { insecurity } \\
\text { cat }\end{array}$ & Coef. & St.Err & $\begin{array}{l}\mathrm{t}- \\
\text { value }\end{array}$ & $\begin{array}{l}\mathrm{p}- \\
\text { value }\end{array}$ & Sig. \\
\hline $\begin{array}{l}\text { Income } \\
\text { generating } \\
\text { capacity_ } \\
\text { cat }\end{array}$ & 3.049 & 0.577 & 5.28 & 0.000 & $* * *$ \\
\hline _cons & 0.001 & 0.535 & 0.00 & 1.000 & \\
\hline $\begin{array}{l}\text { Mean dep } \\
\text { var }\end{array}$ & dent & 0.942 & \multicolumn{2}{|c|}{$\begin{array}{l}\text { SD dependent } \\
\text { var }\end{array}$} & 0.234 \\
\hline Pseudo r-sc & uared & 0.103 & \multicolumn{2}{|c|}{ Number of obs } & 500.00 \\
\hline Chi-square & & 22.844 & \multicolumn{2}{|c|}{ Prob $>$ chi 2} & 0.000 \\
\hline $\begin{array}{l}\text { Akaike cri } \\
\text { (AIC) }\end{array}$ & & 202.584 & \multicolumn{2}{|c|}{$\begin{array}{l}\text { Bayesian } \\
\text { crit. (BIC) }\end{array}$} & 211.01 \\
\hline
\end{tabular}

$* * * \mathrm{p}<0.01, * * \mathrm{p}<0.05, * \mathrm{p}<0.1$

Table 11 the odds ratio of Income generating capacity limitations and Food insecurity

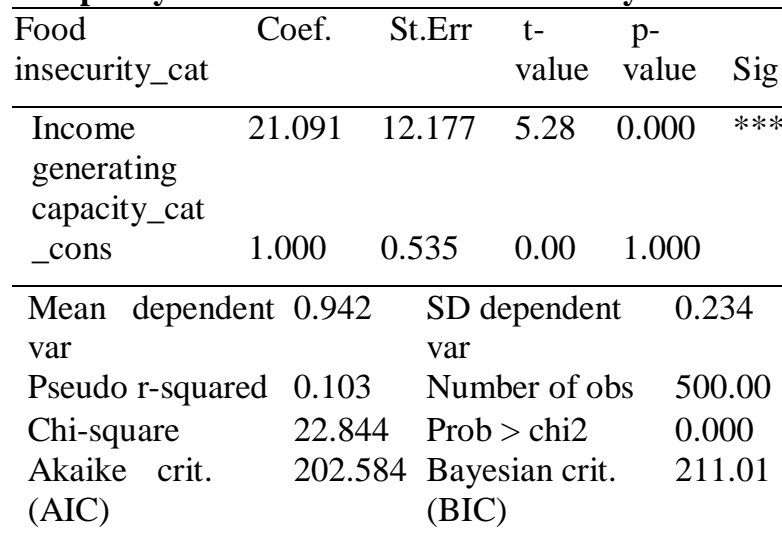

$* * * \mathrm{p}<0.01, * * \mathrm{p}<0.05, * \mathrm{p}<0.1$

From table 11, we observe that when there is income generating capacity limitation $(\mathrm{X}=1)$ the odds of food insecurity $(Y=1)$ is 21 times greater than the odds of food insecurity in the absence of limitations in income generating capacity $(X=0)$. This indicates that if there is a limitation in income generating capacity the likelihood that citizens will face a problem of food insecurity is higher than the case that $x=0$. Hence, we conclude that limitation in income generating capacity brings food insecurity. therefore, hypothesis (c) is ascertained.

At the same time from table 10 we can easily observe that the probability that income generating capacity limitation causes food insecurity is $\mathrm{P}=$ $\frac{e^{b o+b l(x)}}{1+e^{b o+b 1(x)}}$. From the table, we see that the values of $\mathrm{b} 0=0.001 \mathrm{~b} 1=3.05$.

There for, $\mathrm{p}=\left(\frac{\mathrm{e}^{0.001+3.05(\mathrm{x})}}{1+e^{0.001+3.05(\mathrm{x})}}\right)$ then for $\mathrm{x}=1 \mathrm{p}=$ $\frac{2.7182^{0.001+3.05(1)}}{1+\left(2.7182^{0.001+3.05(1)}\right)}=\frac{21.13}{22.13}=0.95$, this shows when there is income generating capacity limitation the probability that there will be a problem of food insecurity is 0.95 or $95 \%$ of the times, hence, whenever there is income generating capacity limitation there is food insecurity.

For $\mathrm{X}=0, \frac{\mathrm{e}^{\mathrm{bo}}}{1+e^{\mathrm{bo}}}=\frac{2.7182^{0.001}}{1+2.7182^{0.001}}=\frac{1.001}{2.001}=0.5$, this shows the probability that there will be food insecurity when no income generating capacity limitation is 0.5 or $50 \%$ of the times greater than that of the existence of income generating capacity. Therefore, comparing the two results $(\mathrm{x}=0$ and $\mathrm{x}=1$ ) it is possible to conclude that the existence of income generating capacity limitation exacerbates the status of food insecurity in urban areas.

The finding is also supported by Cecilia Tacoli et al (2013) stating that low and irregular incomes are the root cause of urban food insecurity. High incidences of malnutrition linked to low incomes and inadequate living conditions make them more vulnerable to a range of diseases.

\subsubsection{Urbanization and food insecurity}

Table 12 Logistic regression coefficient result of Urbanization and food insecurity

\begin{tabular}{|c|c|c|c|c|}
\hline $\begin{array}{l}\text { Food } \\
\text { insecurity_cat }\end{array}$ & Coef. $\quad$ St.Err & $\begin{array}{l}\text { t- } \\
\text { value }\end{array}$ & $\begin{array}{l}\mathrm{p}- \\
\text { value }\end{array}$ & Sig. \\
\hline $\begin{array}{l}\text { urbanization_ } \\
\text { cat }\end{array}$ & $2.361 \quad 0.660$ & 3.58 & 0.000 & $* * *$ \\
\hline _cons & $0.560 \quad 0.627$ & 0.89 & 0.372 & \\
\hline Mean dependent $\mathrm{V}$ & $\begin{array}{rl}0.942 & \mathrm{SD} \\
& \text { var }\end{array}$ & \multicolumn{2}{|c|}{$\begin{array}{l}2 \text { SD dependent } \\
\text { var }\end{array}$} & 234 \\
\hline Pseudo r-squared & 0.044 Num & \multicolumn{2}{|c|}{ Number of obs } & 00.00 \\
\hline Chi-square & 9.634 Prob & \multicolumn{2}{|c|}{ Prob > chi 2} & .002 \\
\hline $\begin{array}{l}\text { Akaike crit. } \\
\text { (AIC) }\end{array}$ & $\begin{array}{r}215.79 \text { Bay } \\
\text { (BIC }\end{array}$ & \multicolumn{2}{|c|}{$\begin{array}{l}\text { Bayesian crit. } \\
\text { (BIC) }\end{array}$} & 24.224 \\
\hline
\end{tabular}


Table 13 the odds ratio of Urbanization and Food insecurity

\begin{tabular}{|c|c|c|c|c|c|}
\hline $\begin{array}{l}\text { Food } \\
\text { insecurity_ } \\
\text { cat }\end{array}$ & Coef. & St.Err & $\begin{array}{c}\mathrm{t}- \\
\text { value }\end{array}$ & $\begin{array}{l}\mathrm{p}- \\
\text { value }\end{array}$ & Sig. \\
\hline $\begin{array}{l}\text { urbanizatio } \\
\text { n_cat }\end{array}$ & 10.606 & 56.995 & 3.58 & 0.000 & $*$ \\
\hline _cons & 1.750 & 1.097 & 0.89 & 0.372 & \\
\hline $\begin{array}{l}\text { Mean depe } \\
\text { var }\end{array}$ & lent & 0.942 & \multicolumn{3}{|c|}{$\begin{array}{l}\text { SD dependent } 0.234 \\
\text { var }\end{array}$} \\
\hline Pseudo r-sc & uared & 0.044 & \multicolumn{2}{|c|}{ Number of obs } & 500 \\
\hline Chi-square & & 9.634 & \multicolumn{2}{|c|}{ Prob > chi 2} & 0.002 \\
\hline $\begin{array}{l}\text { Akaike cr } \\
\text { (AIC) }\end{array}$ & & 15.794 & \multicolumn{3}{|c|}{$\begin{array}{l}\text { Bayesian crit. } \\
\text { (BIC) }\end{array}$} \\
\hline
\end{tabular}

$* * * \mathrm{p}<0.01, * * \mathrm{p}<0.05, * \mathrm{p}<0.1$

As depicted in the above table, table13, that contains the odds ratio, we observe that when there is urbanization $(\mathrm{X}=1)$ the odds of food insecurity $(Y=1)$ is 10.60571 times greater than the odds of food security $(Y=0)$ without urbanization $(X=0)$. This indicates that with the expansion of urbanization the probability of food insecurity is higher than the case where $\mathrm{x}=0$. Hence, we conclude that urbanization intensifies food insecurity among the urban dwellers.

However, as the odds ratio doesn't provide appropriate meanings, we need to convert the odds ratio into the probability value in the following ways. From the above table, it is clearly indicated that the odds ratio is 10.60571 . In this case, the regression equation is given by:

$\ln \left[\frac{\mathrm{p}}{1-\mathrm{p}}\right]=\mathrm{b}_{0}+\mathrm{b}_{1}(\mathrm{x})$

Where: $\mathrm{Ln}=$ the natural logarithm

$\mathrm{P}=$ the short form of $\mathrm{p}(\mathrm{y}=1)$ - the probability that the dependent variable exists.

$\frac{\mathrm{p}}{1-\mathrm{p}}=$ the odds for $\mathrm{p}(\mathrm{y}=1)-$ the probability that $\mathrm{y}=1$ for a given " $\mathrm{x}$ " value divided by the probability that $y=0$ for that " $x$ " value

$\ln \left[\frac{\mathrm{p}}{1-\mathrm{p}}\right]=$ natural logarithm of the odds of food insecurity $\mathrm{p}(\mathrm{y}=1)$

Therefore, $b_{0}=\ln$ of odds when $x=0,1.75: \ln 1.75$ $=0.5596$ and $b_{1}=\ln$ of odds when $x=1,10.60571$ : $\ln 10.60571=2.361393$. To convert the coefficients into odds, the formula is $\mathrm{e}^{\mathrm{b} 0}$ for the odds when $\mathrm{x}=0$ and $\mathrm{e}^{\mathrm{b} 1}$ for the odds $\mathrm{x}=1$, hence $\mathrm{e}^{0.5596}=1.75$, $\mathrm{e}^{2.361393}=10.60571$.
Hence, the regression model based on the odds will be developed as;

$\ln \left[\frac{\mathrm{p}}{1-\mathrm{p}}\right]=\mathrm{b}_{0}+\mathrm{b}_{1}(\mathrm{x})=0.5596+2.361393 \mathrm{X}-$ is indicated in the regression output showing the result of coefficients.

This tells us whenever there is urbanization the log of the odds of food insecurity is greater than the log of the odds of food insecurity when there is no urbanization. $(y=1 / x=1$ or 0$)$. But to make the analysis more plausible, we have to translate the model into probabilities as follows:

$\ln \left[\frac{\mathrm{p}}{1-\mathrm{p}}\right]=\mathrm{b}_{0}+\mathrm{b}_{1}(\mathrm{x})=\mathrm{b}_{0}+\mathrm{b}_{1}$ (declining volume of agricultural food production) take " $e$ " to the power of both sides

$\left[\frac{p}{1-p}\right]=e^{b 0+b 1(x)} \quad$ then calculate the odds for $x=1$ and $\mathrm{x}=0$ and compare the probabilities.

$\mathrm{P}=\frac{\mathrm{e}^{\mathrm{bo}+\mathrm{bl}(\mathrm{x})}}{1+e^{\mathrm{bo}+\mathrm{b} 1(\mathrm{x})}}$. for $\mathrm{X}=1$

$\mathrm{P}=\frac{2.7182^{0.5596+2.361393}(1)}{1+2.7182^{0.5596+2.361393(1)}}=\left(\frac{18.5597}{19.5597}\right)=0.9488$, this shows when there is urbanization the probability that there will be food insecurity is 0.9488 .

For $\mathrm{X}=0, \frac{\mathrm{e}^{\mathrm{bo}}}{1+e^{\mathrm{bo}}}=\frac{2.7182^{0.5596}}{1+2.7182^{0.5596}}=\frac{1.75}{2.75}=0.636$. Hence, the probability that there will be food insecurity even though no urbanization is 0.636 . Based on this we can conclude that the existence of urbanization exacerbates the status of food insecurity in urban areas. Thus, we proved that hypothesis (b) is ascertained.

Sylvia Szabo (2016), has conducted a research to depict out the relationship between urban growth on food security risk. Based on her research findings, less developed countries with a $4 \%$ rate of urban growth have a $66 \%$ probability of being in the high food insecurity risk group. The study further asserted that in many developing countries that experience relatively rapid rates of urban growth, macro-level urbanization processes resulting from poor planning and management of human settlements and physical environment are likely to be strongly associated with greater food insecurity risks. The present study also affirms such assertion as $94.88 \%$ probability of food security risk is observed as a result of the process of urbanization in metropolitan cities. 


\section{Mediation Analysis}

5.1 The Mediating role of income generating capacity limitations in the relationship between urbanization and food insecurity.

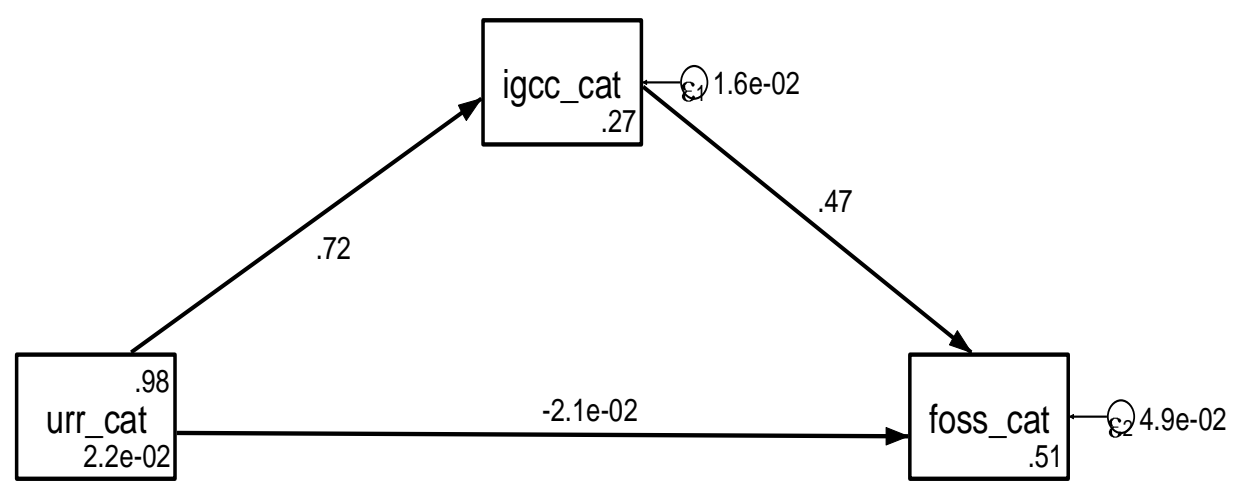

Figure 2 Mediating role of income generating capacity between urbanization and food insecurity

Table 14: Direct and indirect effects of urbanization on food security through income generating capacity Direct

\begin{tabular}{lllllll}
\hline & Coef. & Std. Err & $\mathrm{Z}$ & $\mathrm{P}>\mathrm{Z}$ & [95\%Conf. Interval] \\
\hline $\begin{array}{l}\text { Structural } \\
\text { igcc_cat <- }\end{array}$ & & & & & & \\
\hline urr_cat & .7150028 & .038825 & 18.42 & 0.000 & .6389072 & .7910984 \\
$\begin{array}{l}\text { foss_cat <- } \\
\text { igcc_cat }\end{array}$ & .4667079 & .0777404 & 6.00 & 0.000 & .3143395 & .6190763 \\
urr_cat & -.0211859 & .0874336 & -0.24 & 0.809 & -.1925525 & .1501808
\end{tabular}

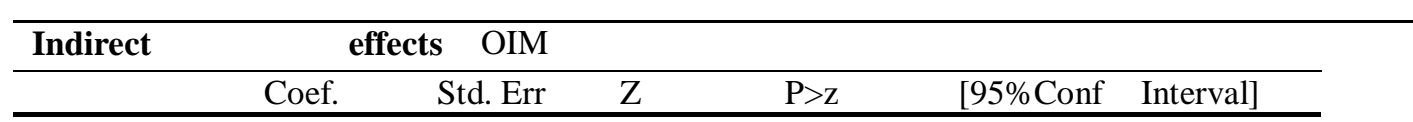

Structural

igcc_cat <-

urr_cat $\quad$ (no path)

foss_cat <-

igcc_cat (no path)

$\begin{array}{llllllll}\text { urr_cat } & .3336975 & .0584635 & 5.71 & 0.000 & .4191111 & .4482838\end{array}$

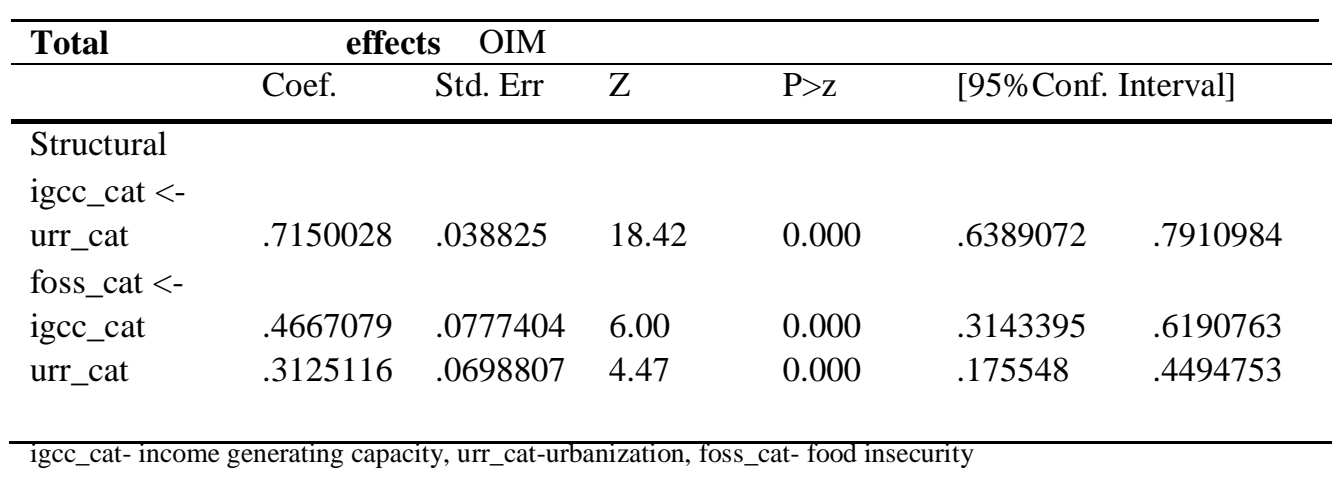


when we observe the mediating role of income generating capacity in the relationship between urbanization and food insecurity as indicated in the path diagram as well as the direct and indirect effect table 14, all the conditions to test mediation are fulfilled. Accordingly, the direct effect of urbanization on food insecurity is 0.021 and the indirect effect is 0.313 . Since the indirect effect is greater than the direct effect, we conclude that income generating capacity mediate the relationship between urbanization and food security. Hence hypothesis (d) is ascertained.

\section{Summary of findings and Conclusion}

The primary objective of this study was to investigate the effect of urbanization on food security emphasizing the mediating role of income generating capacity in the context of Amhara region Ethiopia.

- The present study comes up with the finding that Urbanization affects food security negatively or urbanization is associated with food insecurity. The study revealed that when there is urbanization the probability that there will be food insecurity is 0.9488 or $94.88 \%$ in the Amhara regional state metropolitan cities.

- Majority of the urban resident, which constitutes $42.2 \%$ are earning less than 2000 birr (69.93 \$) per month. This means that $42.2 \%$ of the respondent are earning less than $2.331 \$$ per day. This shows that the urban residents are seriously facing income generating capacity limitations.

- The study also revealed that the income generating capacity limitation of the urban residents affects the food security negatively or it is associated with food insecurity. The present study confirms that when there is income generating capacity limitation, the probability that there will be a problem of food insecurity is 0.95 or $95 \%$ of the times. This is higher than the probability of food insecurity $(0.5$ or $50 \%$ time) that exists with the absence of the income generating capacity.

- The other finding asserted in the study is that income generating capacity limitation mediates that relationship between urbanization and food insecurity. For such an assertion, the study computes both the decomposing of direct and indirect effect and mediation analysis. The direct effect of urbanization on food insecurity is 0.021 and the indirect effect is 0.313 . As the indirect effect is greater than the direct effect, we conclude that income generating capacity mediate the relationship between urbanization and food security.

- Accordingly, we concluded that the rapidly increasing and unmanaged urbanization causing food insecurity among citizens in the region is exacerbated by income generating capacity limitation.

\section{Recommendations}

Based on the conclusions made we recommend policymakers to devise ways to manage urbanization by taking measures such as dealing with rural-urban migration, unplanned outward expansion, and the natural growth in the urban as well as rural areas which is not consistent with the economic growth.

Instead of facing the challenge such as the decline in land productivity, and devising solutions by itself, rural people take migration to cities as the only and ultimate solution to their problems. Hence awareness should be created that their problem could even get worse rather than being solved through migration.

Besides this, it is important to find ways to make farmers beneficial from their farm activities. In this regard, the problem raised by farmers is their inability to settle the debt from fertilizers and selected seeds or at least what they get from selling their produces is used to settle their farm debt. Some policy measures such as subsidizing the farmer or extending the repayment period of their debt are then essential to help farmers lead a stable life and lead their families. The government/concerned body need to make a costbenefit analysis by weighting the pressure from the migration of the farmers and the cost of subsidizing the farmers: hence they need to compare the importance of prevention with curative.

In addition to this, rather than concentrating on urban areas, expanding the family guidance services to the rural areas in order for farmers to have the number of children commensurate with their revenue could be another potential solution to prevent those migrators due to worst rural life.

It is clear that due to outward expansion of cities to the suburb, agricultural land is converted to nonagricultural use and in turn reducing the volume of agricultural foodstuff production on one hand and increasing the proportion of consumers to producers, on the other hand, keeping the problem two-fold. Unfortunately, the vast area of land given to investors remains idle for a long period of time if not forever. Hence, it is important to revise the investment policies and regulate land utilization. 


\section{Acknowledgements}

The researchers would like to acknowledge sample respondents, key informants, and Bahir Dar University. The researchers acknowledge the university because this work was entirely supported by Bahir Dar University, School of Law in 2017 [Research Project Code BDU/RCS/LAW/07/09, 2017].

Conflict of Interest: No conflict of interest.

\section{References}

[1] Axel Hadenius. Democracy and Development. London: Cambridge University Press. (1992).

[2] BOFED. 2013/14 Budget Year Annual Statistical Bulletin. Bahir Dar: BOFED. (2014).

[3] Bremner J. Population and Food Security: Africa's Challenge. Population Reference Bureau. (2012).

[4] C. Tacoli, B. Bukhari, and S. Fisher. Urban poverty, food security and climate change. Human Settlements Working Paper No.37 Rural-Urban Interactions and Livelihood Strategies. London: Human settlement Group, International Institute for Environment and Development (IIED). (2013).

[5] Chen and Ravallion. "Absolute Poverty Measures for the Developing World, 19812004." Proceedings of the National Academy of Sciences of the United States of America, 104/43: 16757-62. (2007).

[6] Cohen, B. Urbanization in developing countries: Current trends, future projections, and key challenges for sustainability. Technology in society, 28, pp 63-80. (2006).

[7] Drescher, A. W., \& Iaquinta, D. L. Urbanization - Linking Development across the Changing Landscape. Rome. FAO. (2002). Retrieved from doi:www.fao.org/fileadmin/templates/FCIT/ PDF/sofa.pdf

[8] Fay, Marianne; Opal, Charlotte. Urbanization without Growth: A Not-SoUncommon Phenomenon. Policy Research Working Paper; No. 2412. World Bank, Washington, DC. (C) World Bank. (2000).
Retrieved from https://openknowledge.worldbank.org/handl e/10986/21373.

[9] Fei,John C.H. and Gustav Ranis Development of the Labor Surplus Economy. (Homewood, IL: Irwin). (1964).

[10] Girardet H. The Gaia Atlas of Cities: New Directions for sustainable Urban Living. London: Gaia Books Limited. (1996).

[11] Golini A. Urbanization and Urban Population. Ethiopia: CSA\& the Institute of Population Research. (1994).

[12] Gugler J. Cities in the developing world: issues, theory, and policy. London: Oxford University Press. (1997).

[13] Haregewoin Bekele. Urbanization and Urban Sprawl. Stockholm: Department of Infrastructure Section of Building and Real Estate Economics. (2005).

[14] Harris, R., J.; Todaro, P., Michael. Migration, Unemployment and Development: A Two Sector Analysis. The American Economic Review, 60(1), pp. 126-142. (1970)

[15] Kasarda. and Crenshaw, E. Third World Urbanization: Dimensions, Theories, and Determinants. Annual Review of Sociology, Vol. 17, pp. 467-501. (1991).

[16] Lewis, A. Development with Unlimited Supplies of Labor. The Manchester School, Vol.22, No.2, pp.139-191. (1954). Retrieved from http://dx.doi.org/10.1111/j.14679957.1954.tb00021.x

[17] Lipton, M. Why Poor People Stay Poor: Urban Bias in World Development. (1977).

[18] Long, R. Urbanization Sociology. Encyclopedia Britannica Article. (1998). Retrieved from http://www.csbs.utsa.edu/users/rlong/intro/ur b.htm.

[19] Martin Ravallion, Shaohua Chen and Prem Sangraula. New Evidence on the Urbanization of Global Poverty. Population and Development Review, Vol. 33, No. 4: pp. 667-701. (2007).

[20] Matuschke I. Rapid urbanization and food security: Using food density maps to identify future food security hotspots: Rome: FAO. (2009). 
[21] McGranahan, G., \& Satterthwaite, D. Urbanisation: Concepts and trends. London: IIED. (2014).

[22] Meister A. Urbanization and Community Development. Athens Center of Ekistics. (1962).

[23] Ministry of Urban Development, Housing and Construction (MUDHCo) and Ethiopian Civil Service University (ECSU). State of Ethiopian Cities Report 2015. (2015).

[24] Montgomery. The urban transformation of the developing world. Science. 319, pp 761764. (2008).

[25] Northam R. M. Urban Geography. New York: John Wiely\& Sons. (1979).

[26] Pawan Urbanization and Its Causes and Effects: A Review. International Journal of Research and Scientific Innovation (IJRSI) Volume III, Issue IX. PP 110-112. (2016).

[27] Pravitasari, A. E. Study on Impact of Urbanization and Rapid Urban Expansion in Java and Jabodetabek Megacity, Indonesia. Kyoto: Kyoto University. (2015). Doi: Https://Doi.Org/10.14989/Doctor.K19347.

[28] Safavi, H, P., The Process of Urbanization and Its Implications for Tourism Sector-A Sustainability Approach: The Case of Famagusta/TRNC. Gazimağusa: Eastern Mediterranean University. (2012).

[29] Satterthwaite, David \& Mcgranahan, Gordon \& Tacoli, Cecilia. Urbanization and its implications for food and farming. Philosophical Transactions of the Royal Society of London. Series B, Biological Sciences. 365. 2809-20. (2010). 10.1098/rstb.2010.0136.

[30] Sean Fox. 'Urbanization as a Global Historical Process: Theory and Evidence from Sub-Saharan Africa', Population and Development Review 38(2), pp: 285-310. (2012).
[31] Stutz F., and Souza A. The world economy: Resources, Location, Trade, and Development. Prentice Hall, New Yersey. (1998)

[32] Sylvia Szabo. Urbanization and Food Insecurity Risks: Assessing the Role of Human Development, Oxford Development Studies, 44:1, 28-48. (2016) doi: 10.1080/13600818.2015.1067292

[33] Tettey, C. Urbanization in Africa in relation to socio-economic development. The University of Akron. (2005).

[34] Tsegaye Tegenu. Urbanization in Ethiopia: Study on Growth, Patterns, Functions and Alternative Policy Strategy. Stockholm: Stockholm University. (2010).

[35] UN DESA. World Urbanization Prospects: United Nations Department of Economic and Social Affairs/Population Division. (2018).

[36] UNECA. Urbanization and Industrialization for Africa's Transformation. Addis Ababa: Economic Commission for Africa. (2017).

[37] UNFPA. State of the World Population 2007: Unleashing the Potential of Urban Growth. United Nations Population Fund, New York. (2007).

[38] UN-Habitat. National Human Settlement Situation Assessment and Plan of Action. Addis Ababa: United Nations Human Settlements Programme. (1996).

[39] UN-HABITAT. The Challenges of Slums. UN-HABITAT. (2003).

[40] Varshney, A. "Urban Bias Perspective in Perspective". [pp 3-24]. Beyond Urban Bias. Varshney, Ashutosh (eds). New York: Routledge. (1993).

[41] WATSON C. Trends in World Urbanization. UK: Centre for Urban and Regional Studies, the University of Birmingham, Proceedings of the First International Conference on Urban Pests. (1993).

[42] World Bank. World Inclusive Cities Approach Paper. Washington: World Bank. (2015). 